\title{
UTILIZATION OF INDIGENOUS FOOD PLANTS IN UGANDA: A CASE STUDY OF SOUTH-WESTERN UGANDA
}

\author{
Enock Musinguzi ${ }^{1}$, Joyce K. Kikafunda ${ }^{1}$, B.T. Kiremire* ${ }^{2}$.
}

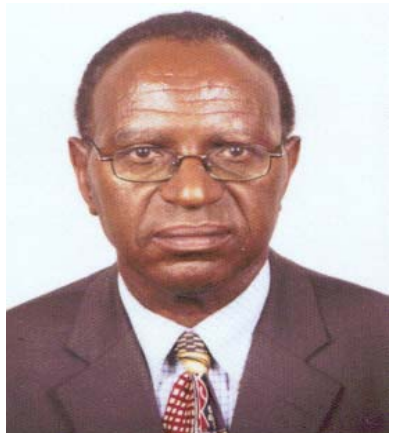

Bernard Kiremire

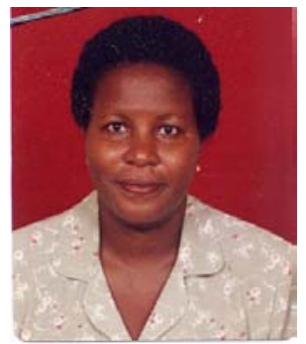

Joyce Kikafunda

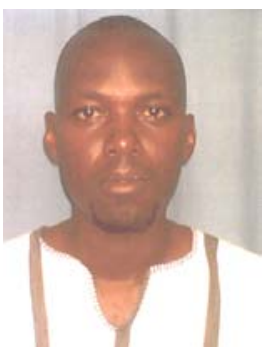

Enock Musinguzi

${ }^{1}$ Department of Food Science \&Technology, Makerere University, Kampala, Uganda;Tel: +256-77-577-971; Fax: +256-41-531641;E-mail: enochmus2003@yahoo.com

$*^{2}$ Corresponding author.

Department of Chemistry, Makerere University, Kampala, Uganda ;Tel: +256-41-540992;

E-mail:kiremire@chemistry.mak.ac.ug 


\section{ABSTRACT}

The purpose of the study was to document and establish the traditional processing methods of indigenous food plants in Rukungiri district. In order to establish the status and level of utilization and processing of indigenous food plants in southwestern Uganda, a baseline survey was carried out using a participatory method of data collection. Respondents in Rukungiri district cited a total of 94 plants that were used for food. Some of the food plants were classified as indigenous to the area, while others were classified as exotic. The food types generally fell into five broad categories, namely; vegetables, fruits, roots/tubers, pulses and cereals. Vegetables and fruits were the most commonly used food plants and the Amaranths species were found to be the most popular vegetables, whereas wild plums (Carissa edulis) and gooseberries (Physalis minima) were cited among the preferred fruit species. In spite of the fact that indigenous/traditional food plants have always ensured food security at the household level, the process of collecting them from the wild, their production,consumption and domestication was found to be on the decline in this area. This decline can be attributed to limited available knowledge on their nutritional content and to the emphasis that is placed on commercial, high yielding exotic plants by both the agricultural extension officers and farmers. The majority of farmers are only interested in the cultivation of crops from which they can earn an income, and because no one has cultivated indigenous food plants with the intention of earning an income from them, the plants have not proved their worth. Although the methods of utilization, especially food preparation, varied from one household to another, boiling, steaming and frying were very common and cross-cutting almost all the households. The principal mode of food preservation cited by households, especially for seeds, was sun drying.

Key words: Survey, indigenous foods, utilisation, Uganda 
French

UTILISATION DE PLANTES ALIMENTAIRES INDIGÈNES EN OUGANDA : ÉTUDE DE CAS DU DISTRICT DE RUKUNGIRI

\section{$R E ́ S U M E ́$}

L'étude avait pour objectif de documenter et établir les méthodes de traitement traditionnelles de plantes alimentaires indigènes du district de Rukungiri. Afin d'établir la situation et le niveau d'utilisation et de traitement des plantes alimentaires indigènes au sud-ouest de l'Ouganda, une étude initiale a été réalisée en utilisant une méthode participative de collecte de données. Les enquêtés du district de Rukungiri ont cité 94 plantes qui sont utilisées comme des aliments. Certaines des plantes alimentaires ont été classées comme étant indigènes à la région tandis que d'autres ont été caractérisées comme étant exotiques. Les types d'aliment sont généralement regroupés en cinq principales catégories : les légumes, les fruits, les racines/tubercules, les légumineuses et les céréales. Les légumes et les fruits représentent les plantes alimentaires les plus utilisées et les espèces Amaranths se sont révélées comme étant les légumes les plus populaires, tandis que les prunes sauvages (carissa edulis) et les groseilles à maquereaux (physalis minima) ont été évoquées parmi les espèces de fruits préférées. En dépit du fait que ces plantes comestibles indigènes/traditionnelles ont toujours assuré la sécurité alimentaire des ménages, il a été constaté que les procédés utilisés pour les recueillir dans la nature, leur consommation et domestication sont en déclin dans ce secteur. Parmi les facteurs qui ont été cités comme étant responsables de ce déclin figure le fait que la connaissance de la valeur des plantes comestibles indigènes est très limitée au sein de la population et des vulgarisateurs agricoles.

Deuxièmement, la majorité des agriculteurs ne sont intéressés que par les cultures dont ils peuvent gagner un revenu, et étant donné que personne n'a cultivé les plantes comestibles indigènes dans le but de les vendre, ces plantes n'ont pas affirmé leur valeur. En général, la production et la consommation de ces plantes comestibles étaient en déclin. Ce déclin peut être attribué à la connaissance limitée de leur composante nutritive assimilable et à l'importance qu'accordent les vulgarisateurs agricoles aux plantes commerciales exotiques à haut rendement. Bien que les méthodes d'utilisation - en particulier celles de préparation des plantes comestibles varient d'un ménage à un autre, les cuissons à l'eau, à la vapeur et en friture étaient les plus communément employées et dans presque tous les ménages. Le principal mode de préservation des produits alimentaires cité par les ménages - surtout pour les semences - était le séchage au soleil.

Mots-clés : Etude, aliments indigènes, utilisation, Ouganda

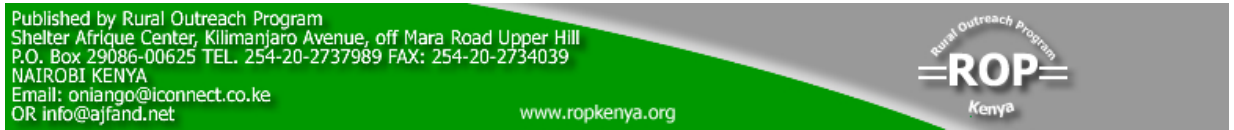




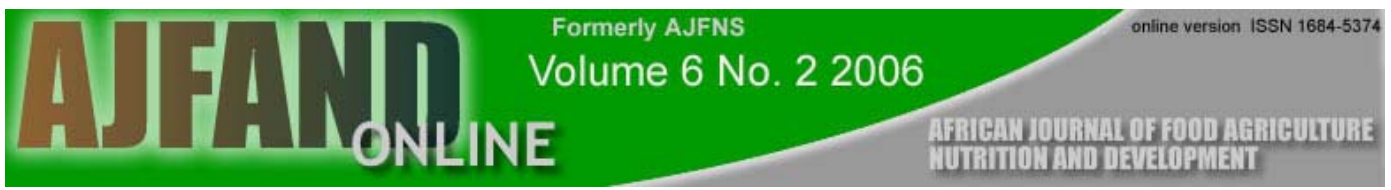

\section{INTRODUCTION}

The local households identified most of the plants found in Rukungiri district as indigenous to the area although information available in the literature shows that some of them are not indigenous to Uganda. For this reason, in this paper, the term Indigenous Food Plants (IFP) is used interchangeably with the term Traditional Food Plants (TFP). The introduction of exotic, high yielding food plants has led to progressively fewer wild plant species being gathered or being brought into cultivation in rural areas. Consequently, some of the neglected and under-exploited indigenous traditional food plants are progressively disappearing as more and more forests are brought under cultivation. IFPs in South western Uganda have not been documented before. The main purpose of this work was to establish and catalogue indigenous food plants in Rukungiri district, to document their traditional utilization, and hence assess their potential for industrial exploitation before they disappear.

In order to establish the status and level of utilisation of the IFPs in Rukungiri district, a baseline survey was carried out. This survey was part of a wider study whose ultimate aim was to assess and document the nutritional value of all indigenous/traditional food plants with a view to promoting their conservation, consumption and industrial exploitation [1]. The study covered 11 sub counties and a total of 116 households. Participatory research/data collection techniques together with a semi-structured questionnaire were utilized to obtain data on all the traditional plants used as food, and the traditional methods of utilizing and preserving them.

This paper specifically reports on indigenous/traditional food plants of south western Uganda, with particular emphasis on their utilization in Rukungiri and Kanungu districts as a milestone and basic foundation for advising policy formulators. The results presented in this paper will supplement the findings of Katende and others who have documented the wild food plants, mushrooms and useful trees and shrubs of Uganda $[2,3]$.

\section{METHODS}

\section{Study area}

The survey on IFPs was carried out in the year 2000 and at that time, the new district of Kanungu had not yet been carved out of Rukungiri district. For this reason, the data from the survey presented here pertains to the current Rukungiri and Kanungu districts. The study area has three agro-ecological zones; lowland or rift valley with altitude varying from $850 \mathrm{~m}$ to $1300 \mathrm{~m}$ above seal level with rainfall up to 40 inches annually, plateau zone with an altitude of $1300 \mathrm{~m}$ to $1700 \mathrm{~m}$ and an average rainfall greater than 40 inches, while the highland zone with a higher altitude $(>1800 \mathrm{~m})$ averages more than 60 inches of rainfall annually. Vegetable cultivation is practiced mainly in the highland zone but Amaranthus species are found in all agro-ecological zones, usually growing unattended. 


\section{Scope of the study}

The study focused on establishing the status of utilization of indigenous/traditional food plants through a baseline household survey. Through the survey, the most frequently used indigenous/traditional food plants as well as the parts of plants, which are used, were established. The methods of preparation of the food plants for consumption and the preservation techniques that are locally employed by the rural communities were investigated.

\section{Household baseline survey}

The selection of the sub-counties was purposely based on ecological zones that were known to be suitable habitats for the IFPs. 11 sub-counties were selected on the basis of the ecological zones that were known to be suitable habitats for the indigenous/traditional food plants. The key criterion for selection of a household was that household members be knowledgeable on the indigenous/traditional plants of the area. The elderly respondents in the households studied were selected with the guidance of the local community mobilisers and local leaders. On average, ten rural elderly persons were selected from each sub- county for individual interviews and interviewed at their place of residence. Before each interview, there was a general discussion on what individuals considered to be IFPs and the objective of the research was explained to each interviewee so as to prevent withholding of information. Semi-structured questionnaires administered in the local language sought knowledge on the following:

- Local names of vegetable and fruit species present and those that are utilized

- Frequency of vegetable and fruit consumption (as a measure of desirability or popularity)

- Part or parts of the plant used

- Local uses of the plants

- Location/habitat where vegetables and fruits are harvested

- Trend in collection of the wild edible food plants

- Methods of preparation for consumption

- Methods of preservation of the food plants

In this paper, emphasis is placed on the utilisation of indigenous/traditional food plants of Rukungiri and Kanungu districts, which are located in south-western Uganda. In order to compare the frequencies of consumption of the various food plants, a weight of 1, 2 and 3 was applied to the frequencies obtained for 'rarely', 'often' and 'very often' respectively, to obtain the composite score, which was used to compute a mean score.

\section{RESULTS}

Table 1 shows the plants cited in Rukungiri district as being used for food in one way or another. In the table, the term frequency is used to show the number of people that cited a particular plant, out of the 116 households that were interviewed. Only those plants, which were cited by more than three respondents, are tabulated. Some of the plants were only cited in the pilot area of Nyakagyeme sub-county where the 
questionnaire was pre-tested. However, the respondents in the 116 households that were subjected to the final questionnaire did not confirm the plants. The table also shows the main methods of utilization of the plants, namely; in the preparation of a staple food, in preparation of sauce, in the generation of revenue for the households, in herbal remedies, in the flavouring of food and, as snacks. The other minor, negligible uses include the processing of juice, use in the making of containers, and in cultural rituals.

Table 2 shows plants that were cited to be vegetables indigenous to Rukungiri district. This group of plants were taxonomically identified after confirmation of their presence in the area. The plants have been listed by the local names and scientific names, together with the methods of how they are traditionally used and their habitat. The percentage utilization in various modes for the species is based on the number of people who cited the food plant (frequency), and on the number of people that cited a particular use of that plant. A high frequency is an indication of the popularity of the particular food plant in Rukungiri area, whereas a small frequency may imply that the plant does not exist in the area where the few respondents were located.

Table 3 shows the parts, which are used for the plants that were confirmed to be present in Rukungiri area. The table shows the parts used as leaf, fruits, flowers, stem and tuber or root. From this table, it is easy to identify fruits and leafy vegetables.

Table 4 shows indigenous/traditional fruits used in Rukungiri district. The table also shows the local name of the plant, habitat, local use, frequency and percentage utilization. The percentage utilization is based on the number of respondents in the survey and those who cited the particular plant.

Table 5 shows information on the frequency of consumption of the various food plants amongst the respondents' households. The frequency of consumption was grouped into three broad categories, namely; rarely consumed (consumed less than two times a month), often consumed (consumed two to eight times a month), and very often consumed (consumed more than eight times per month). In order to compare the frequencies of consumption of the various food plants, a weight of 1,2 and 3 was applied to the frequencies obtained for 'rarely', 'often' and 'very often' respectively, to obtain the composite score, which was used to compute a mean score.

Table 6 presents various methods cited by the respondent households as being used in the preparation of food plants for consumption. The table also shows the number of respondents who cited a particular method of traditional food processing (frequency), out of 107 households, and a percentage based on the two figures. Table 7 shows the methods that were described by households as being used in the process of preserving food plants for storage. Only 77 households responded to this question and the frequency shows the number of households out of the 77 that cited a particular method of food preservation. 


\section{DISCUSSION}

A comprehensive list of food plants used in Rukungiri district is shown in table 1.The list was compiled in the year 2000 before Kanungu district was carved out of Rukungiri district. The compilation was based on a survey that was carried out in the sub-county, which was used in pre-testing the questionnaire known as Nyakagyeme. The list was updated in the course of interviews in the selected eleven sub counties of the then Rukungiri district. Similarly, the method of processing the individual food plants was compiled and updated based on the pretest results from Nyakagyeme sub-county. The food types generally fell into five broad categories, namely; vegetables, fruits, roots/tubers, pulses and cereals. However, it is mostly fruits and vegetables that were classified as indigenous/traditional to the area (Table 2).

The major uses of the plants included provision of staple food and the preparation of relish (sauce). The fruits were found to be predominantly consumed as a snack when ripe, and to a limited extent in making fruit juices. Although there were other uses cited such as in the performance of rituals and in the making of containers, only one plant was cited in each of the two uses, namely, Cleome gynandra (Eshogi) for rituals and Lagenaria sicerari (Omwongo), which is used as a calabash when dry. The fruit of Lagenaria sicerari, which was cited by $1.9 \%$ of the respondents is eaten as a vegetable when it is still young. However, the young fruits of the indigenous/traditional Lagenaria sicerari are not found on both the weekly local markets and the daily urban vegetable markets. As a container, the mature dry fruit or calabash is increasingly becoming popular in the marriage ceremonies, in the central and western parts of Uganda where it is used to serve local drinks.

The table also shows that some of the food plants are sold to contribute to the household income. The first column in the table shows the number of respondents that cited a particular food plant out of the 116 households. This column provides some measure of the popularity of the food plant within the area. For example, a small number of respondents implies that many people in the area are not familiar with the plant, in which case it may not exist in the area. All the plants that were cited by less than three respondents have been excluded from the table. The other columns show the number of respondents who cited a particular use of the plant as a percentage of the total number of respondents who cited the plant. A high percentage in these columns is a measure of how important a particular use is with respect to the number of respondents who cited the particular plant, but not necessarily with respect to the people of Rukungiri. For example, one respondent cited lettuce as being utilized in the making of relish but the plant is not commonly known in Rukungiri district, although it can be found in the large urban markets such as those in Kampala city.

Some of the food plants grow voluntarily on fallowed land during the rainy season or they are cultivated in small backyard gardens. The rest of the food plants, especially fruits, are wild and are collected for home consumption during the rainy seasons (Table 2). The survey further revealed that some indigenous food plants make a contribution to

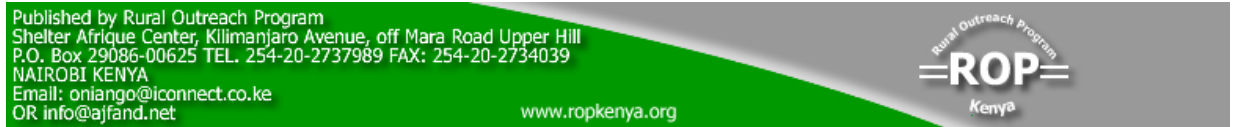


household incomes especially in poor households (Table 2) even when sourced from the wild. In general however, the income derived from the sale of the indigenous/traditional fruits was very small although it can be regarded as very important in the day-to-day running of lives for the rural households who are poor. The ability to generate minimal incomes from indigenous/traditional fruits and vegetables has been reported in previous studies $[4,5,6,7,8,9,10]$. It is possible that FAO's and Lipton and Longhurst's findings, which are contrary to our observations, were based on big commercial farmers who might consider the income from marketing indigenous/traditional fruits and vegetables rather secondary. For the small poor farmers we collaborated with, this was not the case[4, 11].

Three of the vegetables, which were cited in the generation of income, belong to the Amaranthus species; namely Amaranthus dubius, A. graecizans and A. hybridus. The other three vegetables are Cleome gynandra, Solanum nigrum and surprisingly, Urtica massaica, whose leaves have stinging hairs. On the other hand, a comparatively large number of households $(1.9-90.7 \%)$ of the respondents cited three species of indigenous fruits as a source of income generation, with the majority of the respondents (90.7\%) indicating Amatehe (Afromomum anguistifolium) as cash-minting wild fruits (Table 1). Solanum gilo which was cited by $6.9 \%$ of the respondents is boiled and eaten as a vegetable, and has a much wider market in urban markets where it is supplied by commercial farmers.

The indigenous/traditional fruits and vegetables were mainly used as food, in form of snacks, as a relish (sauce) and for medicinal purposes. A distinction between fruits and leafy vegetables can be based on table 3, which shows plant utilization by parts. Among the leafy vegetables, Amaranthus dubius (dodo), Solanum nigrum (eshwiga), pumpkin leaves (ebishusha) and Amaranthus graecizans (enyabutongo) were used by over $80 \%$ of the respondents. Cleome gynandra (eshogi), Amaranthus hybridus (omuriri), pumpkin seeds (entetere), young leaves of beans (ebijamba) and fruits of Solanum anguivi (entakara) were used by $60 \%$ to $80 \%$ of the respondents (Table 1 ). The leafy vegetables of Erucastrum arabicum (eshaaga), Basella alba (enderema) and Urtica massaica (Ekicuragyenyi/Ekicuranganyi) were also used by $30 \%$ and $50 \%$ of the respondents. It should be noted that most of the people in this area know Urtica massaica, which has stinging hairs, as ekicuragyenyi. However, the Bakiga who migrated from Kabale area call it ekicuranganyi. There were other plants such as Ekitongotongo, Kahendarwiko and Omuriri that were given different local names depending on the origin of the respondents. This diversity in names can lead to confusion especially for interviewers who do not hail from the area of a particular survey. In this particular study, the people who carried out the interviews were accompanied by interpreters hailing from Rukungiri and selected by Uganda National Farmers Association.

Generally, indigenous/traditional food plants are used to fill in the relish gaps and in so doing they contribute to the food security and also provide dietary diversity for the people. Many respondents indicated that they use indigenous/traditional vegetables 
whenever other relishes are in short supply or when famine strikes, thereby providing an alternative in times of need. Mnzava has reported similar observations in previous studies [9]. The fruits on the other hand, were mostly harvested from the wild and their utilization was generally lower than that of vegetables (Table 4). The fruits of Solanum gilo (entonga), Physalis minima (entuutu) and Rubus pinnatus (enkyerere) were used by more than $50 \%$ of the respondents. Afromomum anguistifolium (amatehe) and Rhus vulgaris (obukanja), which are wild, are used by between $40 \%$ and $50 \%$ of the people. The fruits of Dovyalis macrocalyx (amatagyengyere) and Tristemma mauritianum (Oburobwenkombe) were used by 30 to $40 \%$ of the respondents in the area. The fruits of Hypericum peplidifolium (otuhaaza), the traditional tomatoes (enyanya enkye) and young fruits of the African bottle gourd (emyongo) were used by between $30 \%$ and 50 $\%$ of the respondents.

\section{Frequency of use of the various food plants}

The frequency of consumption can provide a clue on how important the food plants are regarded in household food security. The respondents to the questionnaire were asked to indicate the frequency of consumption (number of times in a specified period) of the various food plants they used in their homes. This question was elaborately explained and specifically referred to the time when the plants were in season.

In general, the leafy indigenous/traditional vegetables were much more frequently consumed than the fruits (Table 5). The most popular vegetables included Eshwiga (Solanum nigrum), Entonga (Solanum gilo), Ekishuusha (Cucurbita maxima leaves) and the Amaranthus species Amaranthus dubius, A.graecizans and A.hybridus. For the fruits, only the most common exotic fruits were popular. These included mangoes (Emiyembe), oranges (emicuungwa), tomatoes (enyaanya) and passion fruits (obutunda).

We can attribute the low rating of indigenous/traditional fruits to the biased promotion of exotic fruits by Agricultural Extension workers. Indeed, in a follow-up workshop for both the farmers and the agricultural extension workers, the two groups concurred that indigenous food plants are currently accorded a low priority by the National Agricultural Extension Service in spite of the historical and current role they play, in the nutrition and food security of the rural communities. The Agricultural Extension workers lacked information on the plants with regard to their role and knowledge and skills relevant to production, storage and processing technology.

\section{Methods of food plant preparation for consumption}

Generally, the households used traditional food preparation and preservation methods, namely; steaming, mashing and the boiling of staple foods separately from the sauce or boiling of the mixture of the two (katogo). Over three-quarters of the households (77.6 $\%$ ) used boiling, $76.6 \%$ used steaming and $55.1 \%$ used mashing as methods of food preparation. Because the eating habits of Ugandans have been changing fairly fast, the frying of foods, which used to be a culinary practice of town and city dwellers, has been adopted by the rural dwellers and is now becoming a traditional way of preparing some specific dishes. This explains why more than half of the households used frying

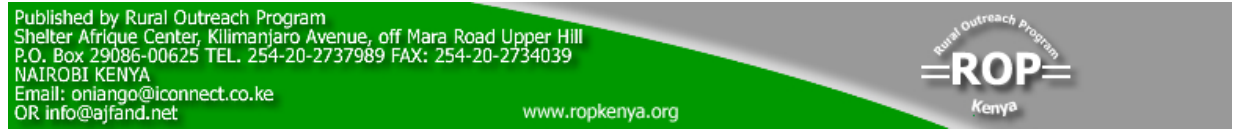


(53.1\%), while about $30 \%$ prepared the food plants into 'Katogo' (casserole). Some respondents mentioned the use of a combination of cooking methods such as boiling prior to frying of the vegetables.

\section{Food preservation methods}

Sun drying is the principal mode of extending shelf-life of food commodities in Rukungiri area. $91 \%$ of the respondents employ sun drying as a means of food preservation. This mode of preservation is the most common in the developing economies like Uganda, as has been observed by other researchers $[12,13,14,1516$, $17,18]$. However, it is applied more frequently to cereals than to fruits and vegetables. In fact, very few people in the area knew that both fruits and vegetables could be dried as a way of preserving them. The other commonly used methods included sun drying accompanied by grinding (22\%) and application of pesticides before storage $(18 \%)$. Food preservation is still very rare and this results in high post-harvest losses of the produce and hence food insecurity and malnutrition.

\section{CONCLUSION}

The purpose of the study was to document food plants indigenous to Rukungiri district. In the course of the survey we hoped to establish the level of utilization of the indigenous food plants, with a view to establishing their potential for industrial exploitation. A total of 94 plants were cited as being used for food in Rukungiri and Kanungu districts. The households who participated in the study classified the food plants either as indigenous to the area or as those that have been introduced to the area (exotic).In this area, vegetables or fruits were found to be the most commonly used indigenous/traditional food plants. Of all the food plants used in the preparation of sauce, the Amaranthus species were found to be the most popular. The most frequently gathered and preferred fruits were the wild plums (Carissa edulis) and the wild gooseberries (Physalis minima). These two fruits and those of amashararazi which is only found in parts of Kihiihi area, have a potential for industrial exploitation for flavonoids extracts which have been strongly implicated as contributors to the health benefits of beverages such as tea and wine, and foods such as fruit and vegetables and have a high price in the global market as food supplements and in the case of amashararazi for wine processing [19].

In spite of the fact that indigenous/traditional food plants have always ensured food security at the household level, the process of collecting them from the wild, their consumption and domestication was found to be on the decline in this area. A number of factors may be responsible for this decline as highlighted below. In view of the fact that knowledge of the value of indigenous food plants is very limited in the population and among Agricultural Extension workers, the plants are not easy to market. For this reason, they do not significantly contribute to most household incomes. Secondly, the majority of farmers are only interested in the cultivation of crops from which they can earn an income and because no one has cultivated indigenous food plants with the intention of earning an income from them, they have not proved their worth.

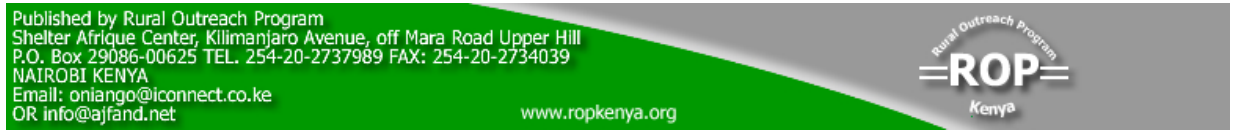


The trend in the collection of edible food plants from the wild has also declined as a result of the encroachment on forests and swamps for habitation and because the habitats are used for the cultivation of the more aggressively promoted cash crops. This decline in the gathering of the food plants and the cessation of their domestication can also be attributed to scanty knowledge that is available on their nutritional content, but largely due to the emphasis that is placed on commercial, high yielding exotic plants by Agricultural Extension officers. The poor soils and the absence of a conservation policy have also contributed to the decline, as has the fact that most of the local communities consider the indigenous food plants to be less nutritious than the exotic food plants, and only fit consumption by the poor communities. It is quite obvious from the findings of this work that unless there is a deliberate attempt to change the attitude of agricultural extension workers and the rural communities, indigenous food plants will become extinct. The change of attitude can only come about through deliberate sensitization based on researched knowledge on the nutritional and health values of indigenous food plants. In particular, vegetables and fruits are sources of anthocyanins and polyphenols among other compounds. Anthocyanins and polyphenols are associated with reduced risks of chronic diseases such as cancer, cardiovascular diseases, and Alzheimer's disease. They are also regarded as important nutraceuticals because of their antioxidant effects, which give them a potential role in prevention of various diseases associated with oxidative stress [19].

\section{ACKNOWLEDGEMENT}

The authors gratefully acknowledge International Development Research Centre (IDRC) and Norwegian Universities' Committee for Development Research and Education (NUFU) for the financial assistance. 


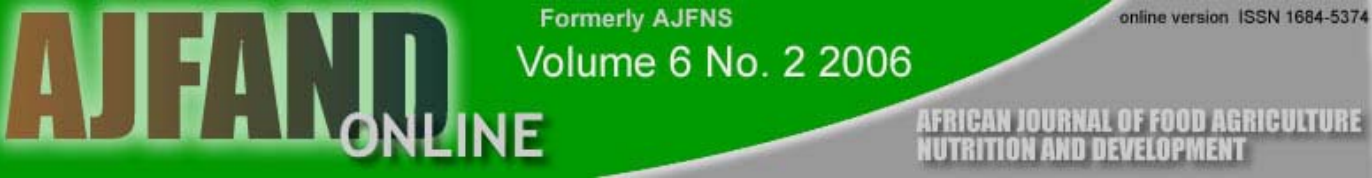

Table 1. Use of Various Food Plants in Rukungiri and Kanungu Districts

\begin{tabular}{|c|c|c|c|c|c|c|c|c|c|}
\hline & Plant name & Frequency & Food & Sauce & Medicine & Cash & Spice & Snack & Other uses \\
\hline & & $\mathrm{n}$ & $\%$ & $\%$ & $\%$ & $\%$ & $\%$ & $\%$ & \\
\hline 1 & Amapapaari & 44 & 18.2 & & & 2.3 & & 81.8 & \\
\hline 2 & Amapeera & 28 & 3.4 & & 3.4 & & 3.4 & 93.1 & \\
\hline 3 & Amatagyengyere & 30 & & & & & & 100 & \\
\hline 4 & Amatehe & 53 & 3.7 & 3.7 & 9.3 & 90.7 & & & \\
\hline 5 & Amayonza & 28 & & 3.1 & & & & 96.1 & \\
\hline 6 & Biringanya & 9 & 11.1 & 88.9 & & 22.2 & & & \\
\hline 7 & Cabbage & 37 & 8.1 & 86.5 & & 24.3 & & 8.1 & \\
\hline 8 & Carrots & 15 & 6.7 & 53.3 & & 6.7 & 26.7 & 26.7 & \\
\hline 9 & Doodo & 104 & & 98.1 & 2.9 & 2.9 & & & \\
\hline 10 & Ebijhamba & 82 & & 100 & 2.4 & & & & \\
\hline 11 & Ebikwaijo & 7 & & & & 14.3 & & 100 & \\
\hline 12 & Ebitekyere & 12 & 41.7 & 66.7 & & & & 8.3 & \\
\hline 13 & Ebitookye & 6 & 33.3 & 16.7 & & & & 50 & \\
\hline 14 & Ebyoozi & 4 & 75 & 50 & & & & & \\
\hline 15 & Ebyuufa & 9 & & 11.1 & 11.1 & & & 77.8 & \\
\hline 16 & Ekicuragyenyi & 38 & 5.3 & 92.1 & 13.2 & 2.6 & & & \\
\hline 17 & Ekifene & 23 & 26.1 & & & 4.3 & & 69.6 & \\
\hline 18 & Ekishuusha & 95 & 6.3 & 97.9 & & & & & \\
\hline 19 & Ekituruguma & 19 & & 84.2 & 26.3 & & & & \\
\hline 20 & Emicuungwa & 21 & 4.8 & & 4.8 & 4.8 & & 42.9 & * \\
\hline 21 & Emiyeembe & 50 & 8 & 2 & & 12 & 2 & 84 & \\
\hline 21 & Empokya & 4 & & 75 & & & & 25 & \\
\hline 22 & Enanaasi & 31 & 15.6 & 6.3 & & 25 & & 78.1 & \\
\hline 23 & Enderema & 40 & & 85.5 & 34.1 & & & 2.4 & \\
\hline 24 & Enkoore & 60 & 6.6 & 95 & 1.7 & & & 10 & \\
\hline 25 & Enkyerere & 75 & 2.7 & 2.7 & 8 & & 1.3 & 93.3 & \\
\hline 26 & Enshwiga & 109 & 1.8 & 98.2 & 16.5 & 0.9 & & & \\
\hline 27 & Ensyanya & 4 & 25 & 75 & 25 & & & & \\
\hline 28 & Entakara & 76 & & 81.6 & 34.2 & & 13.2 & & \\
\hline 29 & Entetere & 83 & 2.4 & 66.3 & 1.2 & & 1.2 & 57.8 & \\
\hline 30 & Entondigwa & 53 & 1.9 & 81.1 & 17 & & & 17 & \\
\hline 31 & Entonga & 101 & 2 & 95 & 5 & 6.9 & & 5 & \\
\hline 32 & Entuutu & 87 & 6.9 & 4.6 & 11.5 & & & 87.4 & \\
\hline 33 & Enyaanya & 51 & 5.9 & 58.8 & 2 & 21.6 & 43.1 & & \\
\hline 34 & Enyabutongo & 94 & 2.1 & 95.7 & 2.1 & 2.1 & & 1.9 & \\
\hline 35 & Enyanya enkye & 6 & & 50 & & & 33.3 & 16.7 & \\
\hline 36 & Eshaaga & 43 & 2.3 & 95.3 & 14 & & & & \\
\hline 37 & Eshenda & 14 & & 64.3 & & & 28.6 & 7.1 & \\
\hline 38 & Eshogi & 87 & 2.3 & 94.3 & 17.2 & 3.4 & 1.1 & & ** \\
\hline 39 & Muhogo & 15 & 6.7 & 93.3 & & & & & \\
\hline 40 & Obucoori & 4 & 75 & & & 25 & & 25 & \\
\hline 41 & Obukanjha & 50 & 2 & 8 & 12 & & & 88 & \\
\hline 42 & Oburobwenkombe & 35 & 8.6 & 11.4 & 14.3 & & & 77.1 & \\
\hline 43 & Obutunda & 44 & 9.1 & 2.3 & 4.5 & 18.2 & & 52.3 & * \\
\hline 44 & Obutunguru & 23 & & 26.1 & & 8.7 & 65.2 & & \\
\hline 45 & Omuriri & 89 & 2.2 & 95.5 & 3.4 & 1.1 & & & \\
\hline 46 & Omwongo & 52 & 67.3 & 32.7 & 9.6 & 1.9 & & 5.8 & *** \\
\hline 47 & Otuhaaza & 54 & 51.9 & 35.2 & 7.4 & & & 22.2 & \\
\hline 48 & Ovacado & 59 & 20.3 & 32.2 & 1.7 & 8.5 & & 47.5 & \\
\hline
\end{tabular}




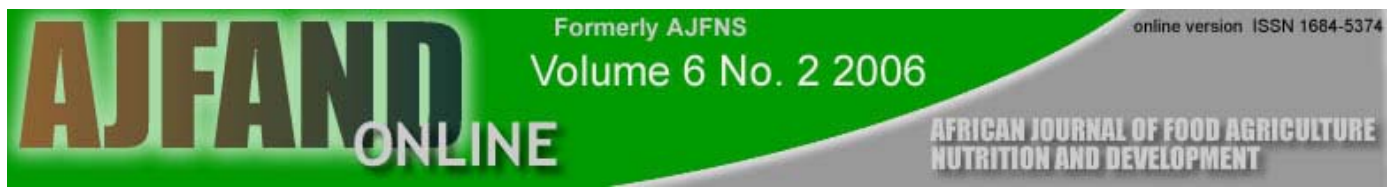

N.B:

- *: $52.4 \%$ and $56.8 \%$ of respondents make juice out of oranges (emicuungwa) and passion fruits (obutunda), respectively.

- $\quad * *: 1.1 \%$ use Cleome gynandra for local rituals

- $\quad * * *: 13.5$ cited use Lagenaria sicerari fruits as containers

- Only plants cited by more than four respondents have been included in the table. 


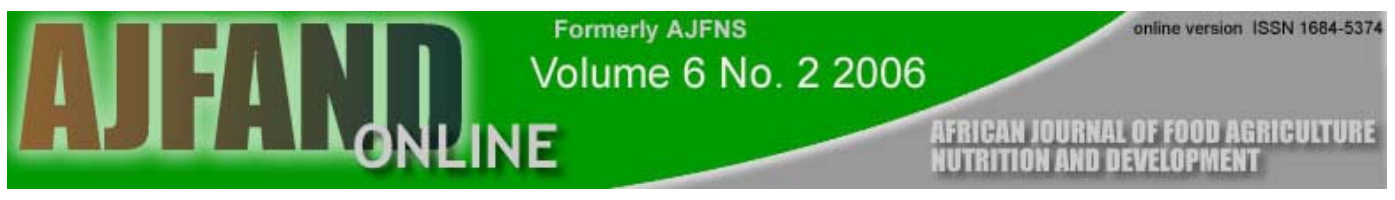

Table 2. Indigenous/Traditional Vegetables of Rukungiri

\begin{tabular}{|c|c|c|c|c|c|c|c|c|}
\hline \multirow[t]{2}{*}{ Local name } & \multirow[t]{2}{*}{ Scientific name } & \multirow[t]{2}{*}{ Habitat } & \multicolumn{6}{|c|}{ Percentage utilization } \\
\hline & & & Food & Sauce & Medicine & Cash & Spice & Snack \\
\hline Amatehe & $\begin{array}{l}\text { Afromomum } \\
\text { anguistifolium }\end{array}$ & W & 3.7 & 3.7 & 9.3 & 90.7 & & \\
\hline Amayonza & Carisa edulis & W & & 3.1 & & & & 96.1 \\
\hline Doodo & Amaranthus dubius & $\mathrm{V}, \mathrm{C}$ & & 98.1 & 2.9 & 2.9 & & \\
\hline Ebijhamba & $\begin{array}{l}\text { Phaseolus vulgaris } \\
\text { (leaves) }\end{array}$ & C & & 100 & 2.4 & & & \\
\hline Ebitekyere & Colocasia esculenta & $\mathrm{C}$ & 41.7 & 66.7 & & & & 8.3 \\
\hline Ebyoozi & Cucurbita maxima fruits & $\mathrm{V}, \mathrm{C}$ & 75 & 50 & & & & \\
\hline Ebyuufa & Munodota junodoii & W & & 11.1 & 11.1 & & & 77.8 \\
\hline Ekicuragyenyi & Urtica massaica & W & 5.3 & 92.1 & 13.2 & 2.6 & & \\
\hline Ekishuusha & Cucurbita maxima leaves & $\mathrm{V}, \mathrm{C}$ & 6.3 & 97.9 & & & & \\
\hline $\begin{array}{l}\text { Ekitongotongo/ } \\
\text { kahendarwiko }\end{array}$ & Amaranthus blitum & $\mathrm{V}, \mathrm{C}$ & & 100 & & & & \\
\hline Ekituruguma & Malva parviflora & $\mathrm{V}, \mathrm{C}$ & & 84.2 & 26.3 & & & \\
\hline Enderema & Basella alba & W & & 85.5 & 34.1 & & & 2.4 \\
\hline Enkoore/Egobe & $\begin{array}{l}\text { Vigna unguiculata } \\
\text { Cow peas }\end{array}$ & $C$ & 6.6 & 95 & 1.7 & & & 10 \\
\hline Enkyerere & Rubus pinnatus & W & 2.7 & 2.7 & 8 & & 1.3 & 93.3 \\
\hline Entakara & Solanum anguivi & $C$ & & 81.6 & 34.2 & & 13.2 & \\
\hline Entetere & Cucurbita maxima seeds & $\mathrm{V}, \mathrm{C}$ & 2.4 & 66.3 & 1.2 & & 1.2 & 57.8 \\
\hline Entondigwa & Capsella bursa & $C$ & 1.9 & 81.1 & 17 & & & 17 \\
\hline Entonga & Solanum gilo & C & 2 & 95 & 5 & 6.9 & & 5 \\
\hline Entuutu & Physalis peruviana & $W, C$ & 6.9 & 4.6 & 11.5 & & & 87.4 \\
\hline Enyabutongo & Amaranthus graecizans & W & 2.1 & 95.7 & 2.1 & 2.1 & & 1.9 \\
\hline Enyanya enkye & Lycopersicon esculentum & $\mathrm{W}, \mathrm{C}$ & & 50 & & & 33.3 & 16.7 \\
\hline Eshaaga & Erucastrum arabicum & $\mathrm{V}, \mathrm{C}$ & 2.3 & 95.3 & 14 & & & \\
\hline Eshenda & Capsicum frutescens & $\mathrm{W}, \mathrm{C}$ & & 64.3 & & & 28.6 & 7.1 \\
\hline Eshogi & Cleome gynandra & $\mathrm{V}, \mathrm{C}$ & 2.3 & 94.3 & 17.2 & 3.4 & 1.1 & \\
\hline Eshwiga & Solanum nigrum & $\mathrm{V}, \mathrm{C}$ & 1.8 & 98.2 & 16.5 & 0.9 & & \\
\hline Obukanjha & Rhus vulgaris & W & 2 & 8 & 12 & & & 88 \\
\hline Oburobwenkombe & Tristema mauritianum & W & 8.6 & 11.4 & 14.3 & & & 77.1 \\
\hline Omuka & Rumex usambarensis & W & 33.3 & 66.7 & & & & \\
\hline Omuriri & Amaranthus hybridus & $\mathrm{V}, \mathrm{C}$ & 2.2 & 95.5 & 3.4 & 1.1 & & \\
\hline Omwongo & Lagenaria sicerari & $\mathrm{V}, \mathrm{C}$ & 67.3 & 32.7 & 9.6 & 1.9 & & 5.8 \\
\hline Otuhaaza & Hypericum peplidifolium & $\mathrm{C}$ & 51.9 & 35.2 & 7.4 & & & 22.2 \\
\hline
\end{tabular}

N.B: W=Wild; C= Cultivated; V=Just grow 


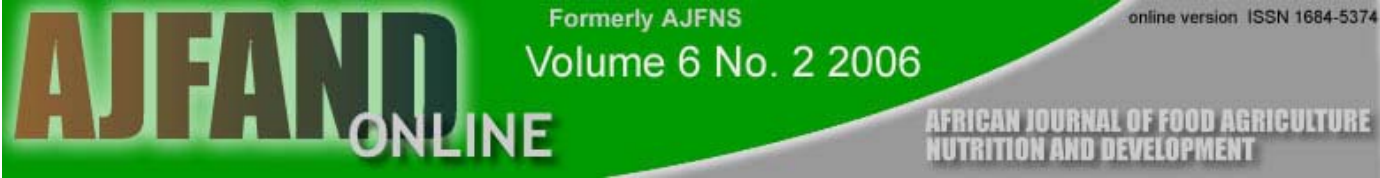

Table 3. Utilization of Plants by Parts

\begin{tabular}{|c|c|c|c|c|c|c|c|c|}
\hline \multicolumn{2}{|r|}{ Plant Name } & Frequency & \multicolumn{6}{|c|}{ Percentage utilization of parts } \\
\hline Local name & Scientific name & & Leaf & Fruit & Stem & Tuber & Seed & Flowers \\
\hline Amatagyengyere & Dovyalis macrocalyx & 34 & & 100 & & & & \\
\hline Amatehe & Afromomum anguistifolia & 57 & 1.8 & 96.5 & 1.8 & & & \\
\hline Amayonza & Carissa edulis & 32 & 3.1 & 96.1 & & & & \\
\hline Ebihimba & Phaseolus vulgaris(seeds) & 86 & 97.6 & 7.2 & & & 100 & \\
\hline Doodo & Amaranthus dubius & 103 & 100 & & & & & \\
\hline Ebijhamba & Phaseolus vulgaris(leaves) & 82 & 100 & & & & & \\
\hline Ebitekyere & Colocasia esculenta & 12 & & & & 100 & & \\
\hline Ebyuufa & Monodora junodoii & 8 & & 100 & & & & \\
\hline Egobe & Vigna unguiculata & 22 & 90.9 & 13.6 & & & & \\
\hline Ekicuragyenyi & Malva parviflora & 38 & 94.7 & 5.3 & & & & \\
\hline Ebyoozi & Cucurbita maxima & 111 & 87.3 & 3.6 & & & & \\
\hline Ekituruguma & Malva parviflora & 19 & 100 & & & & & \\
\hline Enderema & Basella alba & 40 & 92.5 & 7.5 & & & & \\
\hline Enkoore & Vigna anguiculata & 61 & 30.6 & & & & 91.9 & \\
\hline Enkyerere & Rubus pinnatus & 75 & 9 & 91 & 2.6 & & & \\
\hline Entakara & Solanum anguivii & 76 & 2.6 & 80.5 & & & 18.2 & \\
\hline Entetere & Cucurbita maxima(seeds) & 84 & & & & & 100 & \\
\hline Entondigwa & Capsella bursa & 56 & 12.5 & & & & 94.6 & \\
\hline Entonga & Solanum gilo & 102 & 3.9 & 98 & & & & \\
\hline Entuutu & Physalis peruviana & 87 & 6.8 & 97.7 & 2.3 & & 1 & \\
\hline Enyabutongo & Amaranthus graecizans & 90 & 86.3 & 13.7 & & & 2.1 & \\
\hline Enyanya enkye & Lycopersicon esculentum & 5 & & 100 & & & & \\
\hline Eshaaga & Erucastrum arabicum & 43 & 100 & & & & & 2.3 \\
\hline Eshenda & Capsicum frutuscens & 12 & 41.7 & 66.7 & & & & \\
\hline Eshogi & Cleome gynandra & 86 & 97.8 & 2.2 & 1.1 & & & 2.2 \\
\hline Eshwiga & Solanum nigrum & 112 & 99.1 & 0.9 & 1.8 & & & 0.9 \\
\hline Obukanjha & Rhus vulgaris & 50 & 10 & 94 & & & & \\
\hline Oburobwenkombe & Tristema mauritianum & 35 & 11.4 & 88.6 & & & 8.6 & \\
\hline Obutunda & Passiflora edulis & 44 & & 100 & & & & \\
\hline Omuriri & Amaranthus hybridus & 89 & 100 & & & & & \\
\hline Omwongo & Lagenaria sicerari & 55 & 23.6 & 87.3 & & & 1.8 & \\
\hline Otuhaaza & Hypericun peplidifolium & 55 & 12.7 & 96.4 & 1.8 & & 1.8 & \\
\hline Ebyoozi & Cucurbita maxima & 97 & 99.5 & 76 & 1 & & 98.5 & \\
\hline
\end{tabular}

N.B.:\% Utilization is based on number of respondents citing a plant and those citing use of part of plant.

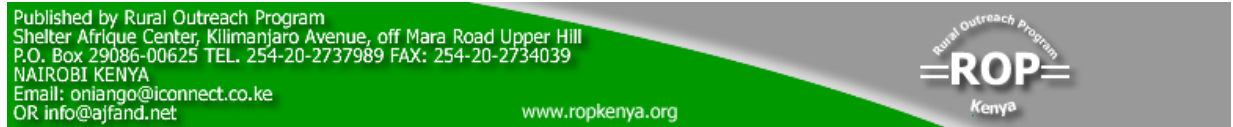




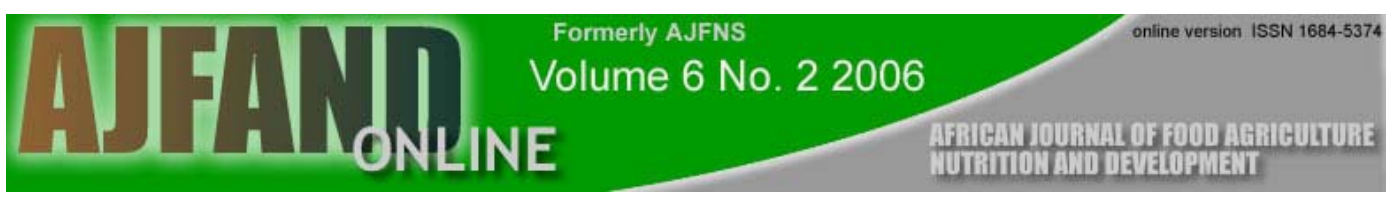

Table 4. Indigenous/Traditional Fruits of Rukungiri

\begin{tabular}{|c|c|c|c|c|c|c|}
\hline $\begin{array}{l}\text { Scientific } \\
\text { name }\end{array}$ & Local name & $\begin{array}{l}\text { Part } \\
\text { used }\end{array}$ & Habitat & $\begin{array}{l}\text { Local } \\
\text { use }\end{array}$ & $\begin{array}{l}\text { Frequency } \\
n=116\end{array}$ & Percentage \\
\hline $\begin{array}{l}\text { Dovyalis } \\
\text { macrocalyx }\end{array}$ & Amatagyengyere & Fruits & Wild & Snack & 34 & 29.3 \\
\hline $\begin{array}{l}\text { Afromomum } \\
\text { anguistifolia }\end{array}$ & Amatehe & Fruits & Wild & $\begin{array}{l}\text { Snack, } \\
\text { medicine }\end{array}$ & 57 & 49.1 \\
\hline Carissa edulis & Amayonza & Fruits & Wild & Snack & 32 & 27.5 \\
\hline $\begin{array}{l}\text { Dioscorea } \\
\text { odoratissima }\end{array}$ & Ebikwa & Fruits & Voluntary/cultivated & juice & 1 & 0.9 \\
\hline $\begin{array}{l}\text { Cyphomandra } \\
\text { betaceae }\end{array}$ & Ebitonganwa & Fruits & Voluntary/cultivated & Snack & 3 & 2.6 \\
\hline $\begin{array}{l}\text { Cucurbita } \\
\text { maxima }\end{array}$ & Ebyoozi & $\begin{array}{l}\text { Fruits, } \\
\text { leaves, } \\
\text { seeds }\end{array}$ & Voluntary/cultivated & $\begin{array}{l}\text { Food, } \\
\text { sauce }\end{array}$ & 4 & 3.4 \\
\hline $\begin{array}{l}\text { Monodota } \\
\text { junodoii }\end{array}$ & Ebyufa & Fruit & Wild & Snack & 9 & 7.8 \\
\hline $\begin{array}{l}\text { Lagenaria } \\
\text { sicerari }\end{array}$ & Emyongo & Fruits & Voluntary/cultivated & Food & 55 & 47.4 \\
\hline $\begin{array}{l}\text { Rubus } \\
\text { pinnatus }\end{array}$ & Enkyerere & $\begin{array}{l}\text { Fruits, } \\
\text { leaves }\end{array}$ & Wild & $\begin{array}{l}\text { Snack, } \\
\text { medicine }\end{array}$ & 79 & 68.1 \\
\hline $\begin{array}{l}\text { Solanum } \\
\text { anguivi }\end{array}$ & Entakara & Fruits & Wild, cultivated & $\begin{array}{l}\text { Sauce, } \\
\text { medicine }\end{array}$ & 76 & 65.5 \\
\hline Capsella bursa & Entondeirwa & $\begin{array}{l}\text { Fruits, } \\
\text { leaves }\end{array}$ & Wild, grown & Sauce & 55 & 47.4 \\
\hline Solanum gilo & Entonga & Fruits & Cultivated & Sauce & 102 & 87.9 \\
\hline $\begin{array}{l}\text { Physalis } \\
\text { peruviana }\end{array}$ & Entuutu & $\begin{array}{l}\text { Fruits, } \\
\text { leaves }\end{array}$ & Wild, cultivated & $\begin{array}{l}\text { Snack, } \\
\text { medicine }\end{array}$ & 88 & 75.8 \\
\hline $\begin{array}{l}\text { Lycopersicon } \\
\text { esculentum }\end{array}$ & Enyanya enkye & Fruits & Wild, cultivated & $\begin{array}{l}\text { Sauce, } \\
\text { spice }\end{array}$ & 5 & 4.3 \\
\hline $\begin{array}{l}\text { Capsicum } \\
\text { frutuscens }\end{array}$ & Eshenda & Fruits & Wild, cultivated & Spice & 12 & 10.3 \\
\hline $\begin{array}{l}\text { Solanum } \\
\text { nigrum }\end{array}$ & Eshwiga & $\begin{array}{l}\text { Fruits, } \\
\text { leaves }\end{array}$ & Voluntary/cultivated & $\begin{array}{l}\text { Sauce, } \\
\text { medicine }\end{array}$ & 112 & 96.5 \\
\hline Rhus vulgaris & Obukanja & $\begin{array}{l}\text { Fruits, } \\
\text { leaves }\end{array}$ & Wild & $\begin{array}{l}\text { Snack, } \\
\text { medicine }\end{array}$ & 50 & 43.1 \\
\hline $\begin{array}{l}\text { Tristema } \\
\text { mauritianum }\end{array}$ & Oburobwenkombe & $\begin{array}{l}\text { Fruits, } \\
\text { leaves }\end{array}$ & Wild & $\begin{array}{l}\text { Snack, } \\
\text { medicine }\end{array}$ & 35 & 30.2 \\
\hline $\begin{array}{l}\text { Passiflora } \\
\text { edulis }\end{array}$ & Obutunda & Fruits & Wild, cultivated & $\begin{array}{l}\text { Snack, } \\
\text { juice }\end{array}$ & 44 & 37.9 \\
\hline Lantana trifolia & Omuhuukye & Fruits & Wild & Snack & 1 & 0.9 \\
\hline $\begin{array}{l}\text { Anona } \\
\text { muricata }\end{array}$ & Omusitaferi & Fruit & Wild & $\begin{array}{l}\text { Snack, } \\
\text { wine }\end{array}$ & 1 & 0.9 \\
\hline $\begin{array}{l}\text { Vangueria } \\
\text { madagascaie }\end{array}$ & Yakobo & Fruits & Wild, grown & Snack & 3 & 2.6 \\
\hline
\end{tabular}




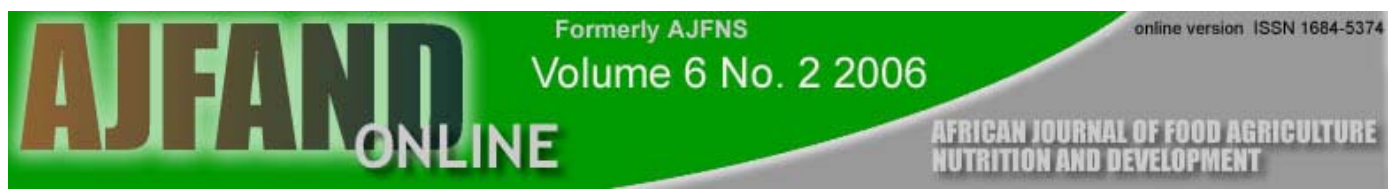

Table 5. Frequency of Consumption of the Various Food Plants

\begin{tabular}{|c|c|c|c|c|c|c|}
\hline Food plant & Frequency & $\begin{array}{l}\text { Rarely } \\
\text { (x1) }\end{array}$ & $\begin{array}{l}\text { Often } \\
\text { (x2) }\end{array}$ & $\begin{array}{l}\text { Very } \\
\text { often } \\
\text { (x3) }\end{array}$ & $\begin{array}{l}\text { Composite } \\
\text { score }\end{array}$ & Mean score \\
\hline Doodo & 103 & 2 & 24 & 77 & 281 & $2.7 * * *$ \\
\hline Enshwiga & 112 & 2 & 30 & 70 & 272 & $2.4 * *$ \\
\hline Entonga & 102 & 2 & 30 & 70 & 272 & $2.7 * * *$ \\
\hline Enyabutongo & 90 & 1 & 40 & 49 & 228 & $2.5 * * *$ \\
\hline Ekishuusha & 97 & 6 & 53 & 38 & 226 & $2.3 * *$ \\
\hline Omuriri & 89 & & 48 & 41 & 219 & $2.7 * * *$ \\
\hline Entetere & 84 & 13 & 48 & 23 & 178 & $2.1 * *$ \\
\hline Ebijhamba & 82 & 12 & 48 & 22 & 174 & $2.1 * *$ \\
\hline Entakara & 76 & 9 & 43 & 24 & 167 & $2.2 * *$ \\
\hline Avocado & 57 & 3 & 9 & 45 & 156 & $2.7 * * *$ \\
\hline Eshogi & 86 & 30 & 46 & 11 & 155 & $1.8^{* *}$ \\
\hline Entuutu & 87 & 30 & 46 & 11 & 155 & $1.8 * *$ \\
\hline Enkyerere & 75 & 29 & 35 & 11 & 132 & $1.8 * *$ \\
\hline Enkoore & 61 & 7 & 38 & 16 & 131 & $2.1 * *$ \\
\hline Enyanya & 45 & & 9 & 36 & 128 & $2.8 * * *$ \\
\hline Emiyembe & 47 & 6 & 7 & 34 & 122 & $2.6 * * *$ \\
\hline Entondigwa & 55 & 9 & 35 & 11 & 112 & $2.0 * *$ \\
\hline Otuhaaza & 55 & 10 & 34 & 11 & 111 & $2.0 * *$ \\
\hline Obutunda & 40 & 2 & 16 & 22 & 100 & $2.5 * * *$ \\
\hline Omwongo & 51 & 11 & 34 & 6 & 97 & $1.9 * *$ \\
\hline Eshaaga & 43 & 6 & 27 & 10 & 90 & $2.1 * *$ \\
\hline Amatehe & 53 & 24 & 22 & 7 & 89 & $1.7 * *$ \\
\hline Enderema & 40 & 9 & 24 & 7 & 78 & $2.0 * *$ \\
\hline Obukanjha & 48 & 28 & 11 & 9 & 77 & $1.6^{* *}$ \\
\hline Enanasi & 31 & 1 & 18 & 12 & 73 & $2.4 * *$ \\
\hline Ekicuragyenyi & 38 & 11 & 22 & 4 & 67 & $1.8 * *$ \\
\hline Amapeera & 28 & 4 & 10 & 14 & 56 & $2.0 * *$ \\
\hline Fene & 25 & 5 & 9 & 11 & 56 & $2.2 * *$ \\
\hline Oburobwenkombe & 33 & 15 & 15 & 3 & 54 & $1.6 * *$ \\
\hline Amatagyengyere & 30 & 17 & 8 & 5 & 48 & $1.6 * *$ \\
\hline Obutunguru & 19 & & 4 & 15 & 53 & $2.8 * * *$ \\
\hline Egobe & 24 & 3 & 18 & 3 & 48 & $2.0^{* *}$ \\
\hline Emichungwa & 20 & 2 & 9 & 9 & 47 & $2.4 * *$ \\
\hline Amayonza & 28 & 14 & 13 & 1 & 43 & $1.5 * *$ \\
\hline Ekituruguma & 19 & 5 & 9 & 5 & 38 & $2.0 * *$ \\
\hline Eshenda & 11 & 1 & 7 & 3 & 24 & $2.2 * *$ \\
\hline Ebitekyere & 11 & 3 & 7 & 1 & 20 & $1.8 * *$ \\
\hline Enyanya enkye & 5 & & 3 & 2 & 12 & $2.4 * *$ \\
\hline Ekubyo & 5 & & 4 & 1 & 11 & $2.2 * *$ \\
\hline Ebyuufa & 7 & 4 & 3 & & 10 & $1.4^{*}$ \\
\hline
\end{tabular}




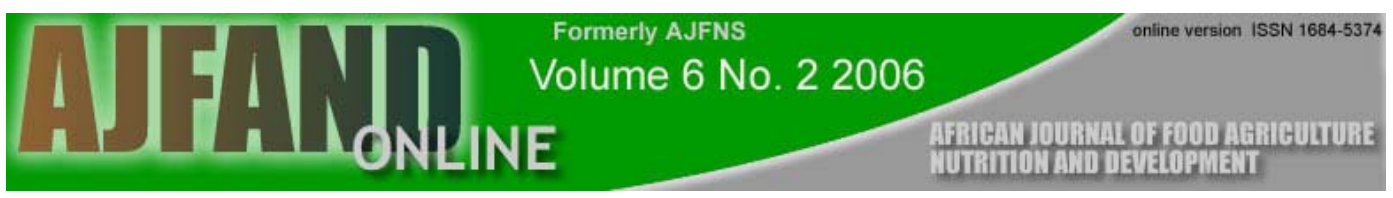

\begin{tabular}{|c|c|c|c|c|c|c|}
\hline$\overline{\text { Ebyoozi }}$ & 4 & & 3 & 1 & 9 & $2.3 * *$ \\
\hline Emizaituni & 3 & & 1 & 2 & 8 & $2.7 * * *$ \\
\hline Nakati & 3 & & 2 & 1 & 7 & $2.3 * *$ \\
\hline Amashararazi & 3 & 1 & 1 & 1 & 6 & $2.0 * *$ \\
\hline Ebitonganwa & 2 & & & 2 & 6 & $3.0 * * *$ \\
\hline Omugonyo & 2 & & 1 & 1 & 5 & $2.5 * * *$ \\
\hline Omuka & 2 & & 2 & & 4 & $2.0 * *$ \\
\hline Obutuzi & 3 & 2 & 1 & & 4 & $2.0 * *$ \\
\hline Kahendarwiko & 1 & & & 1 & 3 & $3.0 * * *$ \\
\hline Ensyanya & 1 & & & 1 & 3 & $3.0 * * *$ \\
\hline Amakondokondo & 2 & 1 & 1 & & 3 & $1.5^{* *}$ \\
\hline Ekitongotongo & 1 & & 1 & & 2 & $2.0 * *$ \\
\hline Omwiha & 1 & & 1 & & 2 & $2.0 * *$ \\
\hline Omundya & 1 & & 1 & & 2 & $2.0 * *$ \\
\hline Yakobo & 1 & & 1 & & 2 & $2.0 * *$ \\
\hline Basiri & 1 & & 1 & & 2 & $2.0 * *$ \\
\hline Ebihama & 1 & 1 & & & 1 & $1.0^{*}$ \\
\hline Ekitongore & 1 & 1 & & & 1 & $1.0^{*}$ \\
\hline Omwisya & 1 & 1 & & & 1 & $1.0^{*}$ \\
\hline Ebikwa & 1 & 1 & & & 1 & $1.0^{*}$ \\
\hline Amatutu & 1 & 1 & & & 1 & $1.0^{*}$ \\
\hline Ebicene & 1 & 1 & & & 1 & $1.0^{*}$ \\
\hline Kashogwitwa & 1 & 1 & & & 1 & $1.0^{*}$ \\
\hline Obugooti & 1 & 1 & & & 1 & $1.0^{*}$ \\
\hline
\end{tabular}

Key: *=Rarely used $* *=$ Often used $* * *=$ Very often used 
Table 6. Methods Used By Households to Prepare/Process Food Plants

\begin{tabular}{lcc}
\hline Method & Frequency & Percentage \\
\hline Preparation (n=107) & & \\
Boiling & 83 & 77.6 \\
Steaming & 82 & 76.6 \\
Mashing & 59 & 55.1 \\
Frying & 57 & 53.3 \\
Roasting & 1 & .9 \\
"Half cook" & 2 & 1.9 \\
"Katogo" & 32 & 29.9 \\
\hline
\end{tabular}

Table 7. Methods Used By Households to Process/Preserve Food Plants

\section{Processing/preservation $(n=77)$}

Sun drying

Dry + grind

Boil + dry + grind

Add pesticide

Add ash

Shelling

Add millet husks

Chop + dry

Add plant leaves

Add banana juice

Dry + roast
90.9

22.1

3.9

18.2

5.2

1.3

2.6

2.6

3.9

1.3

1.3 


\section{REFERENCES}

1. Kiremire BT, Bukenya C, Bukenya-Ziraba R, Nakamatte E, Kikafunda JK, Musinguzi E and EB Rubeihayo $5^{\mathrm{e}}$ Colloque.produits naturels d'origine végétale. Actes du colloque de Sainte-Foy (Quebec), 2001.

2. Katende AB, Birnie A and B Tengnäs Useful Trees and Shrubs for Uganda. Regional Soil Conservation Unit, RSCU. 1995.

3. Katende AB, Ssegawa $\mathbf{P}$ and $\mathbf{A}$ Birnie Wild food plants and mushrooms of Uganda. Regional land Management Unit/Sida, 1999.

4. FAO. United Nations Food and Agriculture Organization Traditional Food plants: A resource book for promoting the exploitation and consumption of food plants in arid, semi-arid and sub-humid lands of E.Africa. FAO Food and Nutrition paper No. 42. FAO, Rome, Italy, 1988.

5. Gockowsk $\mathbf{J}$ and $\mathbf{M}$ Ndumbe The transformation of leafy vegetable cropping system along Cameroon's humid forest margins. In: African indigenous vegetables, pp 46-51. Proceedings of NRI/IPGRI/CPRO workshop, 13-28 January 1997, Limbe, Cameroon (Schippers R and L Budds (Eds). ODA, UK, 1997.

6. Lewis I Network vegetable production in Africa: Promoting the conservation and use of under-utilised and neglected crops. In: Proceedings of the IPGRI international workshop on genetic resources of traditional vegetables in Africa: Conservation and use, 29-31 August 1995, ICRAF-HQ, Nairobi, Kenya, 1997.

7. Rubaihayo EB The Contribution of Indigenous Vegetables to the household food security in Uganda. African Crop Science Conference Proceedings. 1997: 1:1337-1340.

8. Midmore DJ, Vera $\mathbf{N}$ and R Venkataraman Household gardening projects in Asia: past experience and future directions. Technical Bulletin No. 19. Asian Research and Development Centre, Taiwan, China, 1991.

9. Mnzava NA Comparing nutritional values of exotic and indigenous vegetables. In: African indigenous vegetables, $\mathrm{Pp}$ 70-75. Proceedings of NRI/IPGRI/CPRO workshop, 13-28 January 1997, Limbe, Cameroon (Schippers, R. and Budds, L. eds.). ODA, UK, 1997.

10. Chweya JA and PB Eyzaguirre (eds). The biodiversity of traditional Leafy vegetables. International Plant Genetic Resources Institute, Rome, Italy, 1999. 
11. Lipton $\mathbf{M}$ and $\mathbf{R}$ Longhurst The role of agricultural research and secondary food crops in reducing seasonal food variation In: Seasonal variability in third world agriculture: The consequences for food security (D.E. Sahn, ed), Pp 285297 IFPRI, London, 1989.

12. Schippers RR African Indigenous Vegetables: An overview of the cultivated species. Natural Resource Institute/ACP-RU Technical Centre for agricultural and Rural Cooperation. Chatham, UK, 2000.

13. Heid JL and Y Maynard Food Processing Operations-their Management, Machines, Materials and Methods. Avi Publishing Company, Inc. Westport, 1963.

14. Ali HM and IA Sakr Food drying. In: Proceedings of a workshop held at Edmonton, Alberta, 6-9 July 1981. IDRC, Ottawa, Canada, 1981.

15. Bassam MW, Malcolm T, Whitfield C and EY Koroma Problems and Solutions for Natural Convection Solar Crop Drying. In: Proceedings of Solar drying in Africa. Workshop held in Dakar, Senegal 21-24 July 1986.

16. Tchiengue $\mathbf{E}$ and $\mathbf{E}$ Kaplouom Influence of technological factors on the rate of drying vegetables using solar thermal energy. In: Proceedings of solar drying in Africa. Workshop held in Dakar, Senegal 21-24 July 1986.

17. Fleming PD, Ekechukwu OV, Norton B and SD Probert Design, installation and preliminary testing of a natural circulation solar-energy tropical dryer. In: Proceedings of solar drying in Africa. Workshop held in Dakar, Senegal 21-24 July 1986.

18. Arinze AE Solar energy for crop drying in developing countries. In: Proceedings of solar drying in Africa. Workshop held in Dakar, Senegal 21-24 July 1986.

19. Andersen ØM and M Jordheim The anthocyanins. In Flavonoids Ed: Oyvind M.Andersen and Keneth R.Markham 2005 Taylor and Francis. Boca Raton, London, NewYork. 